Relations industrielles

Industrial Relations

\title{
Wokutch, Richard E., Worker Protection, Japanese Style : Occupational Safety and Health in the Auto Industry
}

\section{Wayne Lewchuk}

Volume 48, numéro 2, 1993

URI : https://id.erudit.org/iderudit/050867ar

DOI : https://doi.org/10.7202/050867ar

Aller au sommaire du numéro

Éditeur(s)

Département des relations industrielles de l'Université Laval

ISSN

0034-379X (imprimé)

1703-8138 (numérique)

Découvrir la revue

Citer ce compte rendu

Lewchuk, W. (1993). Compte rendu de [Wokutch, Richard E., Worker

Protection, Japanese Style : Occupational Safety and Health in the Auto Industry].

Relations industrielles / Industrial Relations, 48(2), 378-380.

https://doi.org/10.7202/050867ar

Tous droits réservés @ C Département des relations industrielles de l'Université Laval, 1993
Ce document est protégé par la loi sur le droit d'auteur. L'utilisation des services d'Érudit (y compris la reproduction) est assujettie à sa politique d'utilisation que vous pouvez consulter en ligne.

https://apropos.erudit.org/fr/usagers/politique-dutilisation/ 
que la recherche sur l'utilité des systèmes de rémunération au mérite comme facteur d'augmentation de la motivation et de la productivité est pratiquement inexistante. Cette lacune est par ailleurs très bien identifiée par l'auteur qui conclut à la nécessité d'examiner avec plus de rigueur scientifique le préjugé favorable des gestionnaires à l'endroit des systèmes de rémunération basés sur la performance individuelle.

Marcel BERNARD

Université Laval

Worker Protection, Japanese Style: Occupational Safety and Health in the Auto Industry, by Richard E. WoKUTCH, New York, ILR Press, 1992, 263 p., ISBN 0-87546-186-7 (alk. paper), ISBN 0-87546-187-5 (alk. paper: pbk.)

The debate over the recent success of the Japanese automobile industry continues to be waged by trade unionists, policy makers and academics. The higher average number of days worked per year in Japan and the higher intensity of effort while at work, are believed by many to be critical in explaining the higher levels of Japanese labour productivity. This has raised concerns about the health and safety impact of the Japanese production system, and the phenomenon of death from over work, referred to as karoshi in Japan. Wokutch has made a significant contribution to this debate by examining the health and safety process in Japan and in Japanese transplants in the United States.

There is much to recommend in this book. It is sensitive to the historical context, the role of culture and values, and organizational issues such as worker empowerment in explaining health and safety performance. It also warns the reader of the difficulties non-Japanese scholar have understanding the nuances of Japanese actions.

The section on the history of health and safety legislation, and trends in reported injury and illness rates suggests that the priority given to health and safety in Japan has dramatically shifted over the last seventy years. Between 1950 and 1985, Japan went from a reported injury rate on average four times higher than that found in the United States to a level less than half of that reported by the average American firm. In industries such as automobiles the change is even more dramatic. In plants employing more than 1,000 workers, American employers reported thirty times more accidents per worker than comparable Japanese plants.

How can this dramatic turnaround in relative health and safety performance be explained? Wokutch dismisses the hypothesis that Japanese employers are motivated by different ethical or moral concerns, although this does become somewhat confusing when he discusses the relationship between paternalistic employment philosophies and approaches to health and safety. Instead he sees Japanese employers guided by enlightened self-interest. Central to Wokutch's explanation of the success of the Japanese in dealing with health and safety is the relationship between health and safety practices and constraints created within the Japanese system of lean production. Lean production, which strives for $100 \%$ use of a worker's time, and involves minimal levels of inventories between work stations, dictates that accidents be kept to a minimum as there is 
no slack in the system to absorb temporary unexpected stoppages or temporary employee absences. Behind the Japanese "zero accident" campaigns is the view that accidents are an extreme form of inefficiency and result in disharmony of operations and hence should be minimized.

The Japanese employer's task is made that much easier by the strong cultural pressures to conform in Japanese society which encourages high levels of individual compliance with health and safety regulations. This allows Japanese employers to place more emphasis on demanding that workers avoid hazards rather than engineering the hazards out of the system which is the preferred approach in North America. For instance, the author discusses the example of an open barrel of isocyanates on the shop floor in Japan. An American visitor was extremely concerned about this. The Japanese manager did not feel it was a hazard given that the barrel had a notice on it suggesting it was dangerous and hence workers would avoid it.

A second critical factor behind the low reported accident rates is the strong social pressures to not report accidents placed on Japanese workers by their employers and by their fellow employees. The same pressures which result in workers working through vacation periods and late at night also results in many injuries not being reported. It is considered a personal disgrace, a failure of one's work group, and a failure of the system, if one reports an injury. It is also considered dishonorable to report minor cuts, etc. Nonreporting may also be increased where workers are encouraged to take responsibility for their own safety in a hazardous environment. This may result in workers feeling that injuries are the outcomes of their own inappropriate actions rather than the hazardous conditions in which they work.

Structural factors may also reduce the probability of an accident being reported. The existence of lifetime contracts has serious consequences for workers who are fired or released from an employer mid-career. Such workers have very poor prospects of reemployment at the same level and hence are more likely to adopt strategies, such as not reporting accidents, which ensure continued employment with the firm.

A third factor behind the low rates of reported injuries and illness is the attention given to health and safety by Japanese managers and their willingness to allow workers to be involved in these issues. Joint labour management committees are common in the larger Japanese firms, and the resources management allocates to health and safety exceeds the level commonly found in North America. At the plant level, the number of Japanese management and labour representatives allocated to health and safety per 1,000 workers is approximately seven times higher than that found in the typical big three automobile plant in North America.

But the situation is far from perfect in Japan. Management appears unwilling to improve health and safety standards if it means slowing down the pace of work. There are also concerns that the cramped quarters in many Japanese plants leads to higher levels of dust, heat and fumes. Management legitimates non-action in these areas on the grounds that they are seen as having more to do with the comfort of workers rather than their health. There is also evidence that the situation in small Japanese firms is much less conducive to high standards of health and safety. 
This book leaves little doubt that the relationship between how hard Japanese workers work and the health and safety hazards they face is complex. There are a number of factors which encourage some Japanese employers to take health and safety more seriously than in North America in the interests of uninterrupted production. There are also strong pressures on Japanese workers not to report injuries, raising major doubts about the validity of reported accident rates in Japan. But in the end, one wonders if the Japanese health and safety system is effective in dealing with health and safety hazards which lead to unexpected and temporary disruptions in the production process but less effective in dealing with other types of hazards such as repetitive strain injuries, exposure to toxins, or high levels of fatigue and exhaustion which are less likely to lead to unexpected disruptions. In Japan, premature death may be as telling an indicator of health and safety performance as workplace injuries or fatalities. In the end, the claim that health and safety levels can be positively correlated with productivity under the Japanese system must remain an open question.

Wayne LEWCHUK

McMaster University

\section{GESTION Revue internationale de gestion}

Volume $18, n^{\circ} 2$, mai 1993

Directrice et rédactrice en chef : Francine Séguin

SOMMAIRE :

Politique éditoriale. Note de la rédactrice en chef. Résumés. L'impact socioculturel des pratiques de gestion: le cas de deux entreprises minières en Abitibi - Jean-Pierre DUPUIS. L'influence du pays d'origine des produits sur les évaluations des consommateurs - Alain D'ASTOUS, Sadrudin A. AHMED et Mostafa EL ADRAOUl. L'artiste, l'artisan et le technocrate - Patricia PITCHER. Flexibilité organisationnelle et gestion des ressources humaines - Réal JACOB. Une ère nouvelle en comptabilité de gestion : la comptabilité par activités - Hugues BOISVERT. Une méthode nouvelle de gestion du changement technologique - Eric ALSĖNE et Joël CARIGNAN. Federal Express et l'engagement à la qualité - traduit et adapté par Geneviève SICOTTE. Recensions de livres pour les gestionnaires.

Gestion. Revue internationale de gestion est publiée 4 fois l'an (février, mai, septembre et novembre) par l'École des Hautes Études Commerciales de Montréal. Les bureaux de l'administration sont au 5255 av. Decelles, Montréal, Québec, H3T 1V6

Abonnement annuel (4 numéros) au Québec (TPS et TVQ incluses) : 1 an : 39,96 $\$, 2$ ans : $64,80 \$, 3$ ans : 84,24 $\$$ Autres provinces (TPS incluse) : 1 an : $37 \$, 2$ ans : $60 \$, 3$ ans:78 $\$$ Autres pays : 1 an : $55 \$, 2$ ans : $80 \$, 3$ ans : $115 \$$ 